\title{
Dante, Giotto e as inter-relações entre artes visuais e literatura na Florença do Trecento
}

\section{Tamara Quírico ${ }^{1}$}

Resumo: Dante, ao tecer elogios a Giotto em uma conhecida passagem da Commedia, situa o pintor em uma posição dentro das artes equivalente à sua. Este artigo pretende discutir diálogos possíveis entre pintura e literatura no início do século XIV, examinando a suposta precedência que tradicionalmente se dá ao texto escrito face às representações visuais.

Palavras-chaves: Dante Alighieri, Giotto di Bondone, artes visuais, literatura

\section{Dante, Giotto and the interrelations between visual arts and literature in Trecento Florence}

\begin{abstract}
As Dante praises Giotto in a well-known passage of his Commedia, he puts them both in equivalent positions within art. This paper shall discuss possible dialogues between painting and literature in the beginning of the $14^{\text {th }}$ century, analyzing the supposed precedence traditionally given to the written text when compared to visual representations.
\end{abstract}

Keywords: Dante Alighieri, Giotto di Bondone, visual arts, literature

\footnotetext{
${ }^{1}$ Doutorando em Tecnologias da Comunicação e Cultura- Universidade do Estado do Rio de Janeiro - UERJ. Mestre em Artes e Processo de Criação: Poéticas Contemporâneas na Universidade Federal do Ceará - UFC. Bacharel em Audiovisual e Novas Mídias na Universidade de Fortaleza - UNIFOR.

E-mail: czr.campos@gmail.com; ORCID: https://orcid.org/0000-0001-8339-6634
} 
Credette Cimabue ne la pintura... assim Dante Alighieri (1265-1321) inicia os versos de sua famosa passagem do Purgatorio em que, talvez pela primeira vez, afirma-se não haver mais a disputa entre literatura e pintura quanto à primazia de valores ou concepções. De fato, escreve Alighieri:

Julgava assim Cimabue da pintura/ o campo ter que ora por Giotto é tido,/ que a fama do primeiro se torna obscura./ Assim tirou de um o outro Guido/ da língua a glória, e talvez já é chegado/ quem do ninho eles dois terá varrido.

No trecho final dessa passagem, Dante está se referindo especificamente a dois "Guidos", ativos na Toscana da segunda metade do século XIII: Guido Guinizelli (1230-1276) e Guido Cavalcanti (1255-1300). O primeiro é considerado o fundador do Dolce Stil Novo, que tanta importância teve para os desenvolvimentos literários na Península Itálica nesse momento. Guinizelli, de acordo com a tradição, teria sido sobrepujado por Cavalcanti na "glória da língua", conforme escrevera Dante; este, por outro lado, se coloca como aquele que suplantou o próprio Cavalcanti na qualidade de sua poesia em vulgar.

Dante vê analogias entre o que teria sucedido na literatura e com o que ocorria contemporaneamente nas artes visuais. Cimabue, nome pelo qual ficou conhecido Cenni di Pepo (ca.1240-1302), era considerado o grande nome da pintura florentina no último quartel do século XIII. Foi, de fato, um dos primeiros artistas a romper com a chamada tradição artística bizantina - a maniera greca - que tanta influência havia tido sobre a pintura italiana do Duecento, até que fosse superado por Giotto di Bondone (ca.1265-1337), que tornaria a pintura, enfim, "moderna"3. A tradição historiográfica inaugurada por Giorgio Vasari (1511-1574) em suas Vite, no século $\mathrm{XVI}^{4}$, apresenta o segundo como discípulo do

\footnotetext{
2"Credette Cimabue ne la pintura/ tener lo campo, e ora ha Giotto il grido/ sì che la fama di colui è scura./ Così ha tolto l'uno a l'altro Guido/ la gloria della lingua: e forse è nato/ chi l'uno e l'altro caccerà del nido". Purg. XI, 94-99.

3 Conforme esclarece Luigi Grassi, na "sociedade pré-humanística italiana do Trecento, com a palavra moderno se pretendia afirmar uma dupla relação, e conjuntamente uma separação de ordem histórica: com o período medieval de modo geral, e com o mundo clássico da antiguidade em particular. Tal relação e separação introduzia necessariamente a ideia, desde antes de Vasari, de um certo desenvolvimento ou 'progresso', ascendente no sentido da qualidade e da imitação, das artes do desenho”. Grassi, 1971, p. 419-420.

${ }^{4}$ Le vite de' più eccellenti pittori, scultori e achitettori, conhecido simplesmente como as Vite (as Vidas), foi publicado pela primeira vez em 1550, ganhando em 1568 uma segunda edição escrita pelo próprio Vasari, revista e ampliada. Nesse livro, fundamental para a história da arte, Vasari
} 
primeiro; podemos perceber, portanto, o desenvolvimento de um modelo retórico em que o aluno, em sua genialidade, consegue superar seu mestre - algo semelhante ao que também teria ocorrido entre Dante e seus "Guidos".

Alighieri, assim, parece colocar pintura e literatura no mesmo patamar de importância em seu mais renomado poema. Vale recordar que o sistema educacional medieval era baseado na divisão entre trivium e quadrivium, que agrupavam as sete disciplinas consideradas básicas para a formação do homem no período: Gramática, Retórica e Lógica (ou Dialética), o primeiro, Aritmética, Geometria, Música e Astronomia, o segundo ${ }^{5}$. As disciplinas do trivium e do quadrivium formavam o conjunto das Artes Liberais em que, como se pode perceber, não estavam incluídas atividades que, por lidarem com habilidades manuais, e não apenas intelectuais, eram consideradas menos nobres. À pintura, portanto, era relegado um papel inferior, de artesanato, e não de Arte.

Não para Dante. Ao tecer elogios ao domínio que Giotto havia estabelecido na pintura italiana já nos primeiros anos do Trecento, o poeta florentino situa o pintor em uma posição dentro das artes equivalente à sua. Para Alighieri, nesse momento, com suas respectivas produções, pintura e literatura caminhariam, finalmente, lado a lado.

Neste artigo, no entanto, não desejamos apenas reafirmar que, a partir do século XIV, intensifica-se um processo de valorização das hoje chamadas "belas artes" que culmina no século XVI, quando passam a integrar o grupo das Artes Liberais, e o artista alcança, por fim, o status de intelectual ${ }^{6}$. Queremos mostrar como, por vezes, as inter-relações entre pintura e literatura seguem um caminho diverso do que é tradicionalmente aceito: isto é, de que as fontes escritas necessariamente deveriam ter precedência sobre as imagens que tratam do mesmo tema, e de que o eixo de influência deveria se dar sempre, portanto, no sentido texto-imagem.

redige a biografia de dezenas de artistas italianos, e particularmente toscanos, inaugurando um modelo historiográfico de grande importância, que conheceu ampla difusão nos séculos seguintes. ${ }^{5}$ Queiroz in Mongelli, 1999, p. 13.

${ }^{6}$ Grassi novamente afirma que, no século XIV, "o tema do artista douto por excelência, ou seja, o próprio Giotto, representa o primeiro grande esforço de desvincular os artistas da mortificante sujeição em relação às assim chamadas artes mecânicas, por sua transferência, em pleno direito, ao nível mais alto das artes liberais". Grassi, 1971, p. 420. 
Considerando-se as relações estabelecidas entre Dante e Giotto ou, de modo mais genérico, entre a literatura e a pintura, precisamos destacar de início um ponto: a influência que, sem dúvida, a Commedia exerce sobre representações visuais do Inferno, em geral inseridas no contexto mais amplo do Juízo Final. Como escreve Lucia Battaglia Ricci, pode-se

Autorizar a ideia de que o poema sacro tenha representado uma espécie de divisor de águas cronológico e cultural na definição da tipologia dos demônios, assim como na definição da geografia moral do inferno, de extrema importância para a iconografia. ${ }^{7}$

O aporte da Commedia, de fato, parece evidente de modo particular nas figurações do Diabo. Por exemplo, a partir de meados do século XIV muitos têm as asas de morcego descritas por Dante em seu poema:

Mas foi o meu assombro inda crescente/ quando três caras vi na sua cabeça:/ toda vermelha era a que tinha à frente,/ e das outras, cada qual egressa/ do meio do ombro, que em cima se ajeita/ de cada lado e junta-se com essa,/ branco-amarelo era a cor da direita/ e, a da esquerda, a daquela gente estranha/ que chega de onde o Nilo ao vale deita./ Um par de grandes asas acompanha/ cada uma, com tal ave consoantes:/ - vela de mar vira eu jamais tamanha -/ essas, sem penas, semelhavam antes/às dos morcegos, e ele as abanava,/ assim que, co' os três ventos resultantes,/ as águas de Cocito congelava./ Por seis olhos chorava, e dos três mentos/ sangrenta baba co' o pranto pingava. ${ }^{8}$

Embora não tenha sido Dante o primeiro a descrever demônios alados é, sem dúvida, a Commedia quem populariza e consolida essa iconografia. Ademais, a explicação para a escolha iconográfica de representar os demônios com asas quirópteras decorre, segundo Carlos Nogueira, do fato de que, por serem anjos caídos, não poderiam ter as asas de um pássaro, "que voa à luz do dia", como os anjos são tradicionalmente figurados; para esses anjos rebelados, seriam preferíveis as asas de um

\footnotetext{
${ }^{7}$ Battaglia Ricci, 2000, p. 63-64.

8 "Oh quanto parve a me gran maraviglia/ quand'io vidi tre facce a la sua testa!/ L'una dinanzi, e quella era vermiglia;/ l'altr'eran due, che s'aggiugnieno a questa/ sovresso 'I mezzo di ciascuna spalla, / e sé giugnieno al loco de la cresta:/ e la destra parea tra Bianca e gialla;/ la sinistra a vedere era tal, quali/vegnon di là onde 'l Nilo s'avvalla./ Sotto ciascuna uscivan due grand'ali,/ quanto si convenia a tanto uccello:/ vele di mar non vid'io mai cotali./ Non avean penne, ma di vipistrello/ era lor modo; e quelle svolazzava,/ si che tre venti si movean da ello:/ quindi Cocito tutto s'aggelava./ Con sei occhi piangea, e per tre menti/ gocciava 'I pianto e sanguinosa bava". Inf. XXXIV, 37-54.
} 
morcego, por ser um animal que "ama as trevas e, de um modo absolutamente diabólico, vive de cabeça para baixo" 9 .

Para além da questão das asas de morcego que, conforme mencionado, não são uma criação de Alighieri, devemos considerar outro aspecto iconográfico, este sim derivado de forma mais evidente da Commedia. A partir do segundo quartel do século XIV, de fato, muitas das figuras de Diabo, seja em cenas autônomas do Inferno, ou inseridas em pinturas com o tema do Juízo Final, possuem três cabeças. Dante igualmente não é o primeiro a apresentar um Diabo tricéfalo, uma paródia grotesca da Santíssima Trindade ao ser figurado, também ele, como uno e trino de forma simultânea; acreditava-se, com efeito, que no espírito do mal

Houvesse três faculdades ou atributos opostos àqueles que se dividem entre as três pessoas divinas, assim era natural que para representar o príncipe dos demônios se recorresse a uma figuração apta a fazer frente àquela com que se representava o Deus trino e uno. ${ }^{10}$

Para Dante, portanto, à "Divina Potestade", ao "supremo saber" e ao "primo amor", características de Deus que ele menciona em uma passagem do Inferno ${ }^{11}$, estariam contrapostos a impotência, a ignorância e o ódio do Diabo.

Ainda que não tenha sido sua invenção, é Dante, sem dúvida, quem populariza esse modo de figuração. A partir do segundo quartel do século XIV, portanto, as representações do Diabo seguem preferencialmente o modelo tricéfalo, com três faces unidas: uma à frente, as outras duas nas laterais. Há, no entanto, um detalhe iconográfico nessas imagens diretamente derivado da Commedia: em praticamente todas essas figurações, cada uma das faces diabólicas devora um pecador. Em pelo menos dois modelos encontrados na região da Toscana, na Península Itálica - terra natal de Dante e Giotto, e por isso o recorte geográfico preferencial deste artigo -, o pecador central é explicitamente referido

\footnotetext{
9 Nogueira, 2000, p. 67.

${ }^{10}$ Consoli, 1980, p. 67.

11 "(...) fecemi la divina podestate, la somma sapienza e 'l primo amore" ["(...) fez-me a divina potestade, o supremo saber e o primo amor"]. Inf. III, 5-6.
} 
como Judas, conforme a descrição de Dante:

Para o da frente, a mordida era ligeira/ pena, em confronto com a gadanhada/ que por vez lhe arrancava a pele inteira./ 'Esse, que sofre aí pena dobrada,/ é Judas Iscariote', disse o guia, / 'co' as pernas fora e a cabeça abocada'. ${ }^{12}$

É o que ocorre no ciclo de afrescos finalizado por volta de 1350 por Andrea Orcagna, na Igreja de Santa Croce, em Florença (que inclui uma representação bastante fragmentada do Inferno), e no ciclo de Taddeo di Bartolo na Collegiata de San Gimignano, executado no início dos anos 1390 [Figura 1]. Nas duas cenas as três faces diabólicas são claramente visíveis, mesmo com os danos na pintura florentina, e em ambas a inscrição Giuda, inserida imediatamente abaixo do pecador abocado pela face central, não deixa dúvidas com relação à sua identificação. A partir desse detalhe, é plausível supor que os outros dois condenados, embora não possuam inscrições equivalentes, sejam Cássio e Bruto, os traidores de César, segundo descreve uma vez mais a Commedia: "Dos outros dois, o que a cabeça arria/ da bocarra da cara preta é Bruto,/ que se contorce e cala todavia;/ Cássio é o outro, de corpo tão hirsuto"13.

12 "A quel dinanzi il mordere era nulla/verso'l graffiar, / che talvolta la schiena/ rimanea de la pelle tutta brulla./ 'Quell'anima là sù c'ha maggior pena',/ disse 'I maestro, 'è Giuda Scariotto,/ che 'I capo ha dentro e fuor le gambe mena". Inf. XXXIV, 58-63.

13 "De li altri due c'hanno il capo di sotto,/ quel che pende dal nero ceffo è Brutto:/ vedi come si storce! e non fa motto!;/ e l'altro è Cassio che par sì membrutto'". Inf. XXXIV, 64-67. 


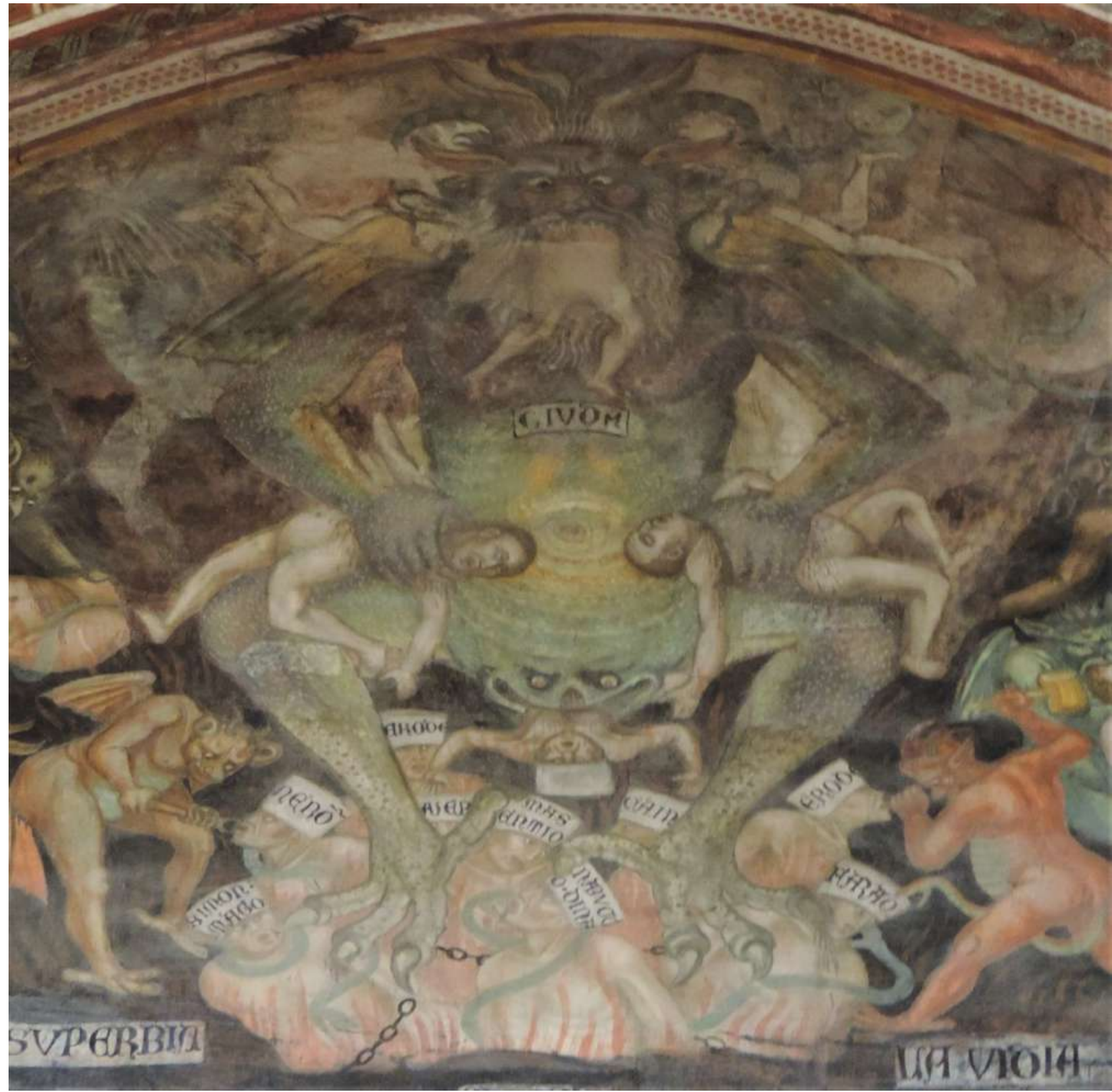

Figura 1. O primeiro exemplo identificado em que ocorrem essas características é Taddeo di Bartolo. Lúcifer, detalhe do Inferno, ca. 1393. Afresco. San Gimignano, Collegiata di Santa Maria Assunta. Fotografia da autora o afresco giottesco da Capela Madalena, no interior do Palazzo del Bargello, em Florença: em seu interior, com efeito, há um ciclo englobando as figurações do Paraíso e do Juízo Final, representados em paredes opostas (na fachada interna da capela e na parede de fundo). Nesse exemplo, portanto, Juízo Final e Inferno estão pintados na mesma parede, em uma composição única, enquanto ao Paraíso é concedido 
maior destaque em uma parede separada ${ }^{14}$. Esse ciclo, que possui ademais a importância de ser um dos primeiros modelos em que se percebem mudanças compositivas nos modos de representação do Juízo Final precisamente o desmembramento do tema em mais de uma cena -, foi provavelmente concebido por Giotto pouco antes de sua morte, em janeiro de 1337, e executado por seus assistentes em seguida, no mesmo ano.

O afresco do Juízo Final está bastante danificado: de fato, conserva-se praticamente somente o terço inferior de toda a pintura parietal. No entanto, justamente a figura do Diabo está em um estado de preservação bastante razoável, possibilitando uma análise um pouco mais detalhada; nela, vemos de pronto as grandes asas de morcego - contudo, ao contrário da descrição dantesca, são discerníveis somente dois pares de asas, e não três. São claramente identificáveis também as três faces diabólicas devorando três pecadores [Figura 2], detalhes iconográficos significativos que indicam a provável influência da Commedia sobre Giotto - $\mathrm{a}$ isso somemos o detalhe de que Vasari aponta a presença de um suposto retrato de Dante entre os eleitos do Paraíso ${ }^{15}$.

\footnotetext{
${ }^{14}$ Não é possível desenvolver neste espaço uma análise sobre a atribuição desse ciclo, nem sobre os temas representados - há autores como Jérôme Baschet, por exemplo, que defendem que, em vez da cena do Juízo Final, há somente o Inferno, em direta contraposição ao Paraíso na parede oposta. Cf. Baschet, 1993, p. 359. Para uma discussão mais aprofundada, que esclarece os motivos para defendermos se tratar de uma figuração do Juízo Final, e não do Inferno, ver Quírico, 2014a, particularmente o capítulo 2.

${ }_{15} \mathrm{Na}$ Vita de Giotto, escreve Vasari que "Il quale fra gl'altri ritrasse, come ancor oggi si vede, nella capella del palagio del podestà di Firenze, Dante Alighieri (...)" ["O qual retratou entre outros, como ainda hoje se vê, na capela da potestade de Florença, Dante Alighieri (...)"]. Vasari, 1997, p. 150.
} 


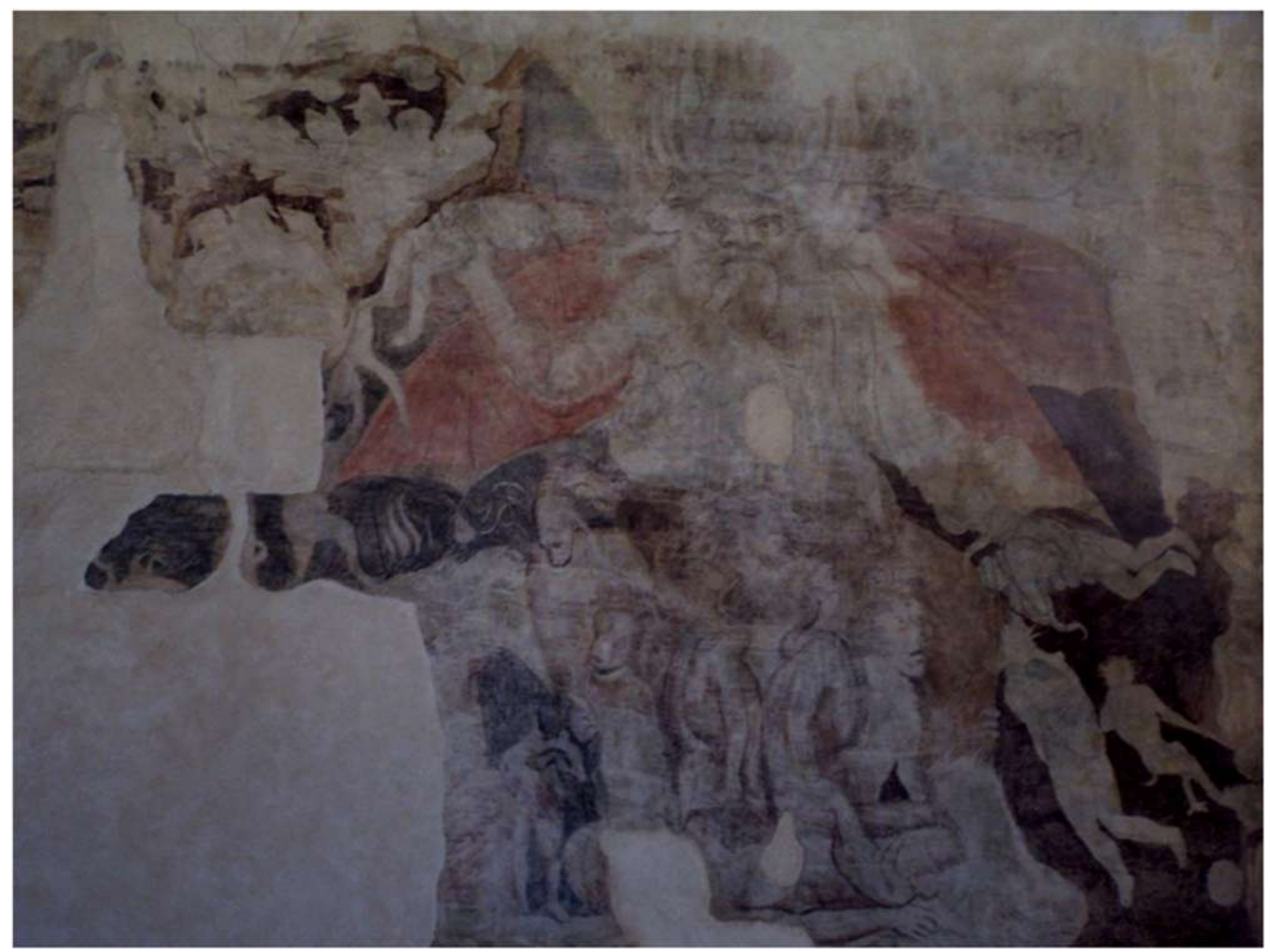

Figura 2 Giotto di Bondone e seguidores. Lúcifer, detalhe do Juízo Final, 1337. Afresco. Capela da Madalena, Palazzo del Bargello, Florença. Fotografia da autora
Quase contemporâneo aos afrescos giottescos no Palazzo del Bargello é o chamado ciclo do Trionfo della Morte, pintado provavelmente por Buonamico Buffalmacco entre 1336 e 1341 no Camposanto de Pisa. Esse conjunto de pinturas engloba, além do afresco do Triunfo da Morte (primeira cena e carro-chefe do ciclo, e que, desse modo, o nomeia contemporaneamente) [Figura 3], representações do Juízo Final e do Inferno, além de um último afresco com a Tebaide ${ }^{16}$. Assim como em

16 O tema da Tebaide se relaciona à vida eremítica escolhida por alguns monges e frades da Idade Média. A palavra, com efeito, indica lugares solitários e desertos, e tem sua origem etimológica no grego thēbaís, ou seja, "região próxima a Tebas", no Alto Egito, e que foi um centro do anacoretismo cristão nos séculos II e III d.C. Garzanti Linguistica.

No conjunto do ciclo do Camposanto de Pisa, esse afresco apresenta ao observador um modo de vida alternativo que poderia levar à salvação, embora não seja, é claro, uma figuração do Paraíso cristão. Como escreve Chiara Frugoni, "depois do Trionfo, do Juízo e do Inferno, que têm como 
Figura 3 Florença, também no ciclo pisano há uma nova configuração nos modos Buonamico Buffalmacco. Visão geral do Ciclo do Trionfo dela Morte (acima) e Triunfo da Morte (abaixo), ca. 13361340. Afresco. Pisa,

Camposanto. Fotografias e montagem da autora de representação do tema do Juízo Final (para além do fato de estar inserido em um conjunto temático mais amplo): mas, ao contrário do que ocorre no ciclo do Bargello, em Pisa são o Juízo Final e o Inferno que formam cenas separadas, ainda que postas lado a lado na mesma parede, e separadas por uma moldura pintada ${ }^{17}$.
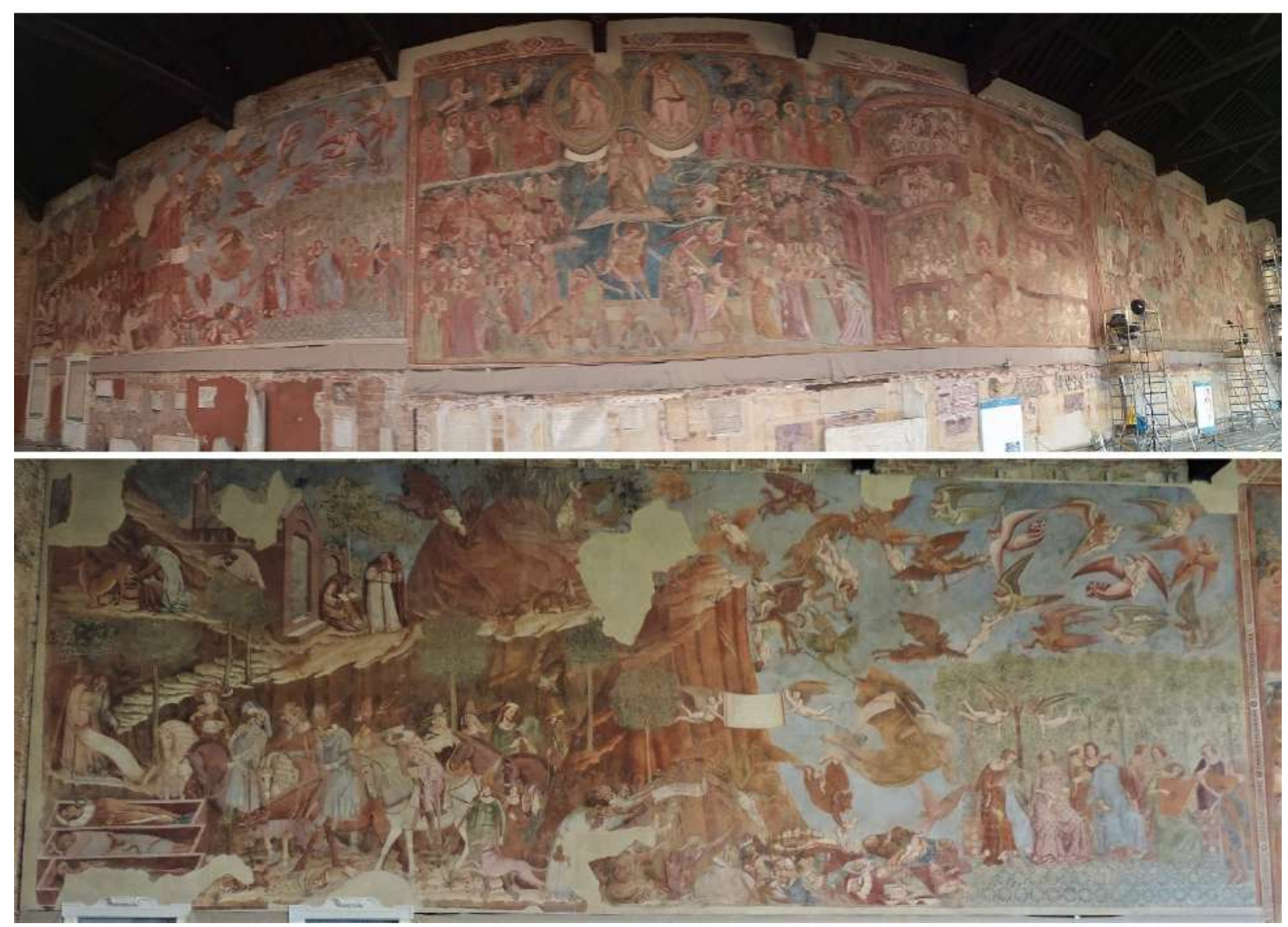

O Diabo no Inferno do Camposanto de Pisa difere da descrição dantesca ao não incluir os pares de asas, mas as alusões à Commedia estão

discurso dominante o terror (...), chega-se, com a Tebaide, finalmente a um 'discurso em positivo', dado que as Vidas dos Santos Padres querem sugerir exemplos de virtude, garantidores finalmente do paraíso (...). De fato os Santos Padres recebem a eterna beatitude porque abandonam de todo o século, tratam o corpo como um obstáculo a vencer, 'renunciando a toda coisa dileta', transcorrendo a vida em 'ânsias e 'suspiros'”. Frugoni, 1988, p. 1585.

17 Novamente, para uma discussão mais ampla sobre esses desenvolvimentos compositivos e iconográficos nas representações do Juízo Final no século XIV, ver Quírico, 2014a. 
presentes nas três cabeças demoníacas, por exemplo. Há um detalhe no Inferno, em particular, que indica a influência de Dante: a inclusão de Maomé em um dos círculos, próximo à boca do Inferno; o profeta é reconhecível não apenas pelo turbante, mas principalmente por uma inscrição junto à sua cabeça, ainda hoje parcialmente legível $(\text { Macometto })^{18}$. Não há exemplos visuais anteriores ao poema em que seja possível identificar Maomé, o que nos ajuda a compreender o aporte do texto dantesco nesse detalhe específico da iconografia infernal.

Referências evidentes ao texto dantesco, porém, que demonstram de modo claro a ascendência do texto do poeta florentino sobre as representações do Juízo Final e do Inferno, eram as inscrições que, até o fim do século XIX, ainda podiam ser lidas em ambos os afrescos: muitas eram transcrições literais de trechos da Commedia, como versos do Purgatorio que se liam abaixo do Inferno, e especialmente a passagem lasciate ogne speranza, voi ch'intrate, que Dante leu sobre a porta do Inferno ao ingressar com seu mestre Virgílio no locus infernal19.

É clara, desse modo, a influência de Dante sobre as representações do Inferno, e do Diabo em particular, de meados do século XIV em diante. Devemos considerar, sem dúvida, que na maior parte dos casos ocorre uma simplificação das descrições da Commedia; isso é perceptível mesmo nas figurações do Diabo. Não encontramos sua representação com as três faces de cores diferentes, conforme narra Alighieri20; embora quase todos

\footnotetext{
18 "Mentre che tutto in lui veder m'attacco,/guardommi e con le man s'aperse il petto,/dicendo: 'Or vedi com'io mi dilacco!/ vedi come storpiato è Mäometto!'” "Enquanto a olhá-lo eu, fixamente, estaco,/ fitando-me, co' as mãos rasga-se o peito,/ e diz: 'Agora vê como me achaco;/ vê como Maomé está desfeito!'”]. Inf. XXVIII, 28-31.

19 "Per me si va ne la città dolente,/ per me si va ne l'etterno dolore,/ per me si va tra la perduta gente./Giustizia mosse il mio alto fattore:/ fecemi la divina podestate,/la somma sapienza e'l primo amore./ Dinanzi a me non fuor cose create/ se non etterne, e io etterno duro./ Lasciate ogne speranza, voi ch'intrate'./ Queste parole di colore oscuro/ vid'io scritte al sommo d'una porta (...)" ["Vai-se por mim à cidade dolente,/ vai-se por mim à sempiterna dor,/ vai-se por mim entre a perdida gente./ Moveu justiça o meu alto feitor,/ fez-me a Divina Potestade, mais/ o supremo saber e o primo amor./ Antes de mim não foi criado mais/ nada senão eterno, e eterna eu duro./ Deixai toda esperança, ó vós que entrais./ Essas palavras vi, num tom escuro/ escritas sobre o alto de uma porta (...)"]. Inf. III, 1-11.

20 "Oh quanto parve a me gran meraviglia/ quand'io vidi ter facce a la sua testa!/ L'una dinanzi, e quella era vermiglia;/ l'altr' eran due, che s'aggiugnieno a questa/ sovresso 'I mezzo di ciascuna spalla, / e sé giugnieno al loco de la cresta:/ e la destra parea tra bianca e gialla;/ la sinistra a vedere era tal, quali/vegnon di là onde 'I Nilo s'avvalla" "Mas foi meu assombro inda crescente/ quando três caras vi na sua cabeça:/ toda vermelha era a que tinha à frente,/ e das duas outras, cada qual egressa/ do meio do ombro, que em cima se ajeita/ de cada lado e junta-se com essa,/ branco-
} 
sejam representados com as três cabeças (seguindo o modelo estabelecido de uma face central e duas faces laterais), há uma uniformização tanto no formato quanto nas cores em cada pintura. Da mesma forma, ele não é mostrado com metade do corpo coberto de gelo, seguindo a descrição dantesca ${ }^{21}$.

Se considerarmos as funções religiosas que se esperaria de representações visuais do Juízo Final e do Inferno - que buscavam, fundamentalmente, a conversão dos fiéis na tentativa de livrá-los da condenação ao fim dos tempos ${ }^{22}$ - parecia mais eficaz que o Diabo pudesse ser contemplado de corpo inteiro, dominando de forma imponente toda a região infernal. Não raro nessas imagens ele era mostrado, ademais, defecando suas vítimas previamente engolidas - ou talvez também as deglutindo, conforme podemos interpretar nos exemplos em que, no lugar dos genitais, há outra singular e inquietante cabeça, como ocorre na representação do Diabo no afresco do Inferno da Collegiata de San Gimignano.

Se Dante e sua Commedia exercem tanta influência na iconografia do Inferno, em particular na do Diabo, porque justamente ele está sendo citado como argumento para o ponto desenvolvido neste artigo? A questão que desejamos colocar, portanto, é: antes de influenciar as artes visuais com seu poema mais renomado, teria Dante sido igualmente influenciado por uma ou mais fontes visuais para conceber sua visão infernal?

Devemos considerar um aspecto importante nessa análise: não é por causa do poema florentino que as instâncias do Além cristão - Inferno e Paraíso - passam a ser figuradas com maior detalhamento nas artes visuais. Com efeito, desde antes da redação da Commedia percebemos um maior destaque do Inferno, especialmente, nas figurações do Juízo

\footnotetext{
amarelo era a cor da direita/ e, a da esquerda, a daquela gente estranha/ que chega de onde o Nilo ao vale deita"]. Inf. XXXIV, 37-45.

21 "Lo 'mperador del doloroso regno/ da mezzo 'I petto uscia fuor de la ghiaccia" ["E agora o rei do triste reino eu vejo,/ de meio peito do gelo montante"]. Inf. XXXIV 28-29. Uma importante exceção é o o afresco de Nardo di Cione no ciclo com o tema do Juízo Final realizado na Capela Strozzi, na Igreja de Santa Maria Novella, em Florença, provavelmente entre 1354 e 1357. Há que se considerar, no entanto, que esse afresco é o único que busca representar de modo mais fidedigno a descrição infernal da Commedia.

22 Sobre isso, ver Quírico, 2014b.
} 
Final. Em muitas imagens do tema anteriores ao Duecento, a área infernal era apenas prenunciada por sua entrada - seja um caldeirão, uma caverna ou a boca de Leviatã. Nos casos em que o Inferno era representado, pouco se mostrava dos castigos. A partir de meados do século XIII, ao contrário, passa-se não apenas a representar efetivamente o cenário do Inferno, como também a detalhar de modo cada vez mais específico os castigos infernais ${ }^{23}$.

Ambos - textos e imagens - são influenciados, sem dúvida, por um mesmo conhecimento de base, criando importantes inter-relações entre eles. Precisamos recordar, particularmente nesse sentido, que a Commedia faz parte de uma longa tradição literária tardo-antiga e medieval dedicada à descrição de visões do Além, que remonta ao menos a meados do século II (quando foi escrito o chamado Apocalipse de São Pedro). Ao longo de todo o Medievo diversos relatos, descrevendo a viagem que alguém empreendeu, fisicamente ou em sonho, ao Inferno e ao Paraíso, impulsionam a imaginação dos fiéis. A Commedia, inserindose nessa linhagem, torna-se, no entanto, uma descrição tão forte e definitiva do Além cristão a ponto de fazer desnecessária qualquer visão posterior. O poema dantesco é, assim, não somente o ápice como também o ponto final dessa tradição literária. Paradoxalmente, o esgotamento das visões do Além na literatura teve efeito oposto nas manifestações visuais do fim da Idade Média, tornando ainda mais vívidas as representações do Paraíso e do Inferno a partir do segundo quartel do século XIV - e, a partir do século XV, começam a surgir, ainda que de forma rara e esporádica, também figurações do Purgatório no contexto do Juízo Final, o que, provavelmente, também se deve à popularidade da Commedia e às descrições dos três loci do Além cristão.

$\mathrm{Na}$ Toscana, a primeira obra em que há uma maior elaboração iconográfica da região infernal é o mosaico executado por Coppo di Marcovaldo e seu ateliê no teto do Batistério de San Giovanni, em Florença [Figura 4]. Realizado no último quartel do século XIII,

\footnotetext{
${ }^{23}$ Na própria Península Itálica há notórias exceções, como o afresco na Basílica de San Michele, em Sant'Angelo in Formis (ca.1080) e o mosaico na Igreja de Santa Maria Assunta, em Torcello, pouco posterior. Em ambos, tanto o interior do Paraíso como do Inferno são mostrados, havendo ainda indicações de punições diversas. No entanto, dentro do contexto mais amplo de representações visuais do tema do Juízo Final na Europa, é somente no fim do século XIII que esse detalhamento iconográfico efetivamente se consolida.
} 
percebemos como, nesse trabalho, ao Inferno é dada uma proeminência maior do que a usual até então, embora ele possua as mesmas dimensões que a representação do Paraíso que a ele se opõe; a composição aparentemente confusa da área infernal difere sensivelmente do modo como a região paradisíaca é mostrada.

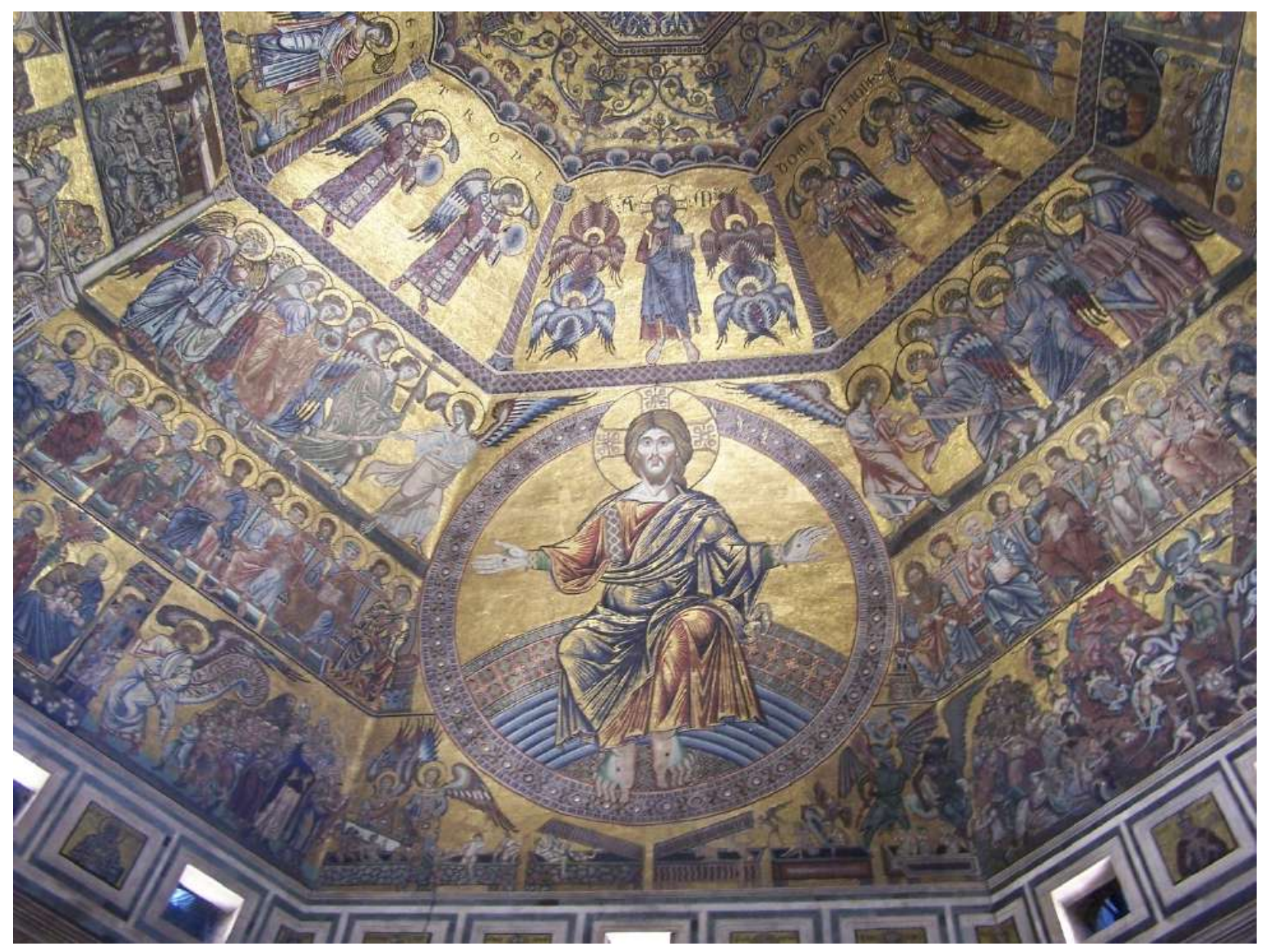

Figura 4 Com essa diferença na composição de ambas as regiões do Além, Coppo

Coppo di Marcovaldo e seguidores. Juízo Final, ca. 1270-1290. Mosaico. Florença, Batistério de San Giovanni. Fotografia da autora não somente faz com que o Inferno atraia o olhar do espectador de forma mais evidente, mas também que a ênfase na representação infernal recaia sobre o Diabo, sentado sobre uma espécie de tablado em chamas, na área central do locus. Ele é apresentado como uma figura monstruosa com barba, chifres e grandes orelhas; de cada uma delas sai uma serpente, que abocanha um condenado. $O$ próprio Diabo engole um deles, de quem se vê somente a metade inferior do corpo. No restante do espaço, castigos diversos são mostrados; dentre tantos pecadores sendo torturados, um em particular nos chama a atenção, por ser o único passível de ser identificado. De fato, no canto inferior direito da cena surge a figura de 
is $^{25}$.

Judas sendo enforcado por um demônio, claramente reconhecível devido à inclusão de uma inscrição a seu lado, Giuda.

Nos primeiros anos do século XIV, Giotto é contratado por Enrico Scrovegni para realizar a decoração da capela de sua família, em Pádua. Dedicada a Santa Maria della Carità, a Capela Scrovegni (ou Capela da Arena) foi construída na esperança de remir os pecados da família, que enriquecera graças à usura de seu pai, Reginaldo (não por acaso identificado como um dos pecadores colocados no Inferno por Dante ${ }^{24}$ ). O afresco do Juízo Final [Figura 5] encerra o ciclo narrativo concebido pelo pintor, com as cenas das vidas da Virgem (iniciando com as histórias de Joaquim e Ana, pais de Maria) e de Cristo nas paredes laterais.

Assim como ocorrera no mosaico do Batistério florentino, também nesse afresco Giotto enfatiza a região do Inferno em contraposição ao Paraíso, que sequer é representado (há somente o cortejo dos eleitos que voltam o olhar para o Cristo Juiz). O Inferno está colocado na metade inferior esquerda da composição (tendo o Cristo como referência - ou seja, ele está à direita do observador). Embora, a princípio, pudéssemos imaginar que essa localização indicasse uma menor importância do registro infernal no contexto mais amplo da representação do Juízo Final, ela cumpre um aspecto fundamental: esse local é o mais próximo do olhar do espectador e, portanto, o mais adequado para a representação do Inferno dentro de um contexto moralizante e didático em que se inseririam as possíveis funções religiosas das imagens com o tema do Juízo Final.

\footnotetext{
24 "E un che d'una scrofa azzurra e grossa/segnato avea lo suo sacchetto bianco,/ mi disse: 'Che fai tu in questa fossa?"' ["E um tal, que de uma porca azul e grossa/ tinha o emblema na bolsa alva pintado,/ me interpelou: 'Que fazes nesta fossa?'”]. Inf. XVII, 64. Esse era o brasão da família Scrovegni, possibilitando a identificação do pecador.

25 As pinturas, colocadas nas paredes dos edifícios religiosos, desenvolvem uma narrativa em que, com frequência, é exposta a história cristã, desde a criação do universo até o fim do mundo. Ou seja, uma narrativa que apresenta as cenas do Antigo e do Novo Testamentos, encerrando a história precisamente com a cena do Juízo Final. Temos, portanto, a concepção da igreja cristã como um microcosmo. Se Giotto, na Capela Scrovegni, não inclui as passagens do Antigo Testamento, podemos considerar, por outro lado, que as histórias de Ana e Joaquim de certo modo sintetizam o que ocorrera antes da vinda de Cristo.
} 


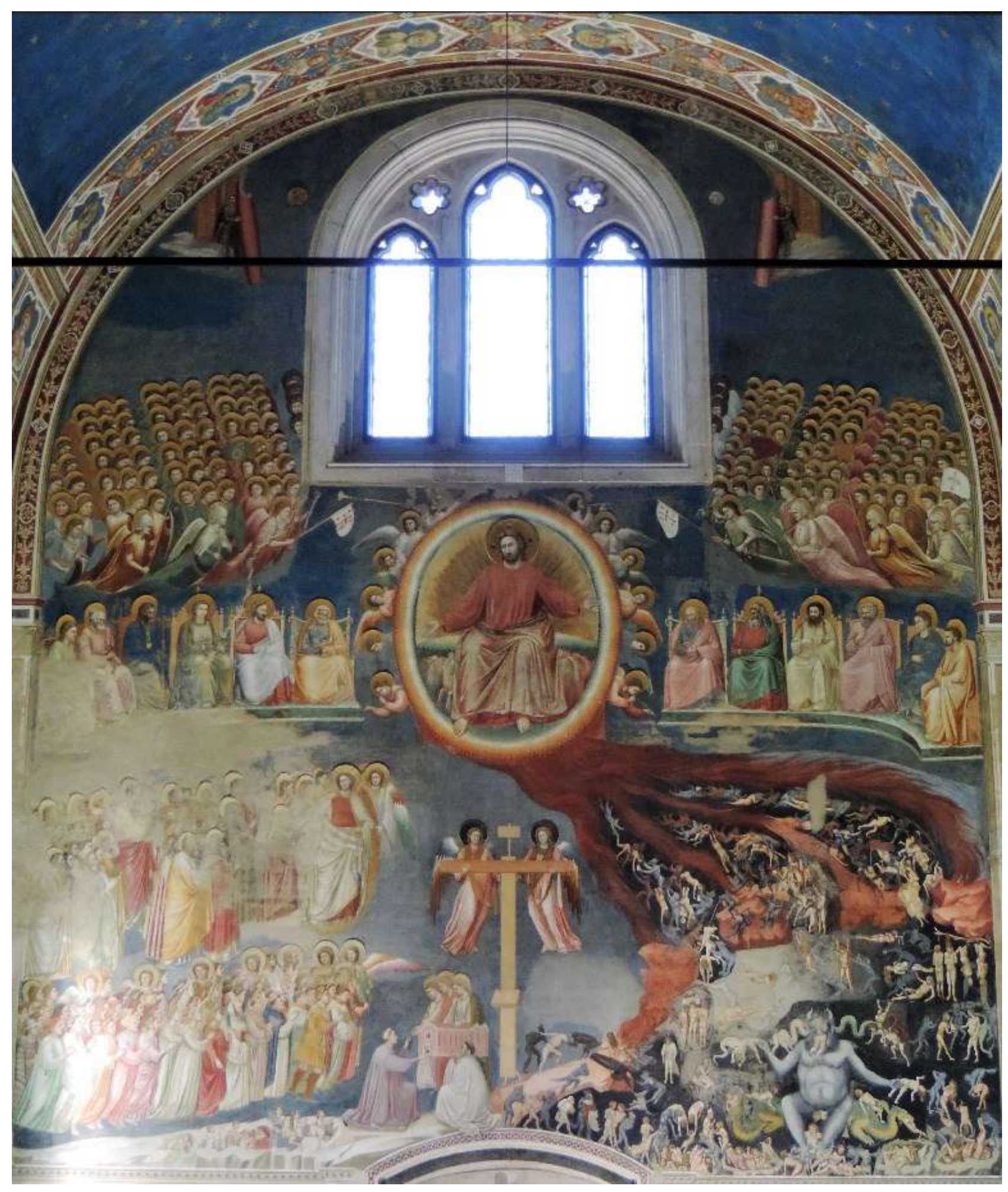

Figura 5

Giotto di Bondone.

Juízo Final, 1305-

1307. Afresco. Pádua,

Capela Scrovegni.

Fotografia da autora 
Antes de prosseguir, devemos ter em mente uma questão importante: a decoração de toda a cúpula do Batistério de San Giovanni, em que se integra a composição com o tema do Juízo Final, é elemento fundamental ao considerarmos os desenvolvimentos artísticos de Florença em fins do Medievo. Precisamos ponderar, de início, o fato de que o Batistério foi "o coração da vida eclesiástica da cidade"26 desde sua fundação (a reconstrução do edifício foi iniciada em meados do século XI, tendo sido consagrado em 1128, quando se tornou oficialmente o Batistério de Florença). Essa posição Ihe conferia grande importância nos contextos político e religioso da cidade: era o local onde ocorriam as investiduras de cavaleiros, por exemplo, assim como outros juramentos solenes, além da principal festa religiosa da cidade, a de seu santo padroeiro - o próprio João Batista.

Desse modo, tendo tamanha importância política e religiosa, é evidente que também sua decoração - tanto no exterior como no interior do edifício - teria destaque no conjunto artístico de Florença naquele momento. De modo todo particular sua grandiosa cúpula; afinal, ela seria continuamente vista e contemplada por todos aqueles que ingressavam no edifício religioso - e não podemos desprezar que o fundo dourado, elemento unificador de todas as cenas da cúpula, desperta de imediato a atenção de qualquer observador dentro do Batistério, possibilitando que essas imagens cumpram de modo adequado suas funções religiosas ${ }^{27}$.

Ademais, devemos considerar ainda que, no contexto da cúpula, o elemento que, sem dúvida, possui maior destaque visual é o Cristo Juiz, concedendo, assim sendo, maior proeminência à representação do Juízo Final. É preciso ter em conta, por fim, ainda outro ponto: esses mosaicos "eram na infância e juventude de Dante os mais notáveis trabalhos da arte

\footnotetext{
${ }^{26}$ Crociani, 1997, p. 13.

$27 \mathrm{O}$ uso do fundo dourado nas pinturas medievais se deve a questões estéticas, religiosas e também sociais. Como escreve Jean-Claude Schmitt, "é sobre um fundo dourado, como numa espécie de fundamento ontológico, que se desenha e se colocam as outras cores" (Schmitt, 2007, p. 391). O ouro serve "simultaneamente para engrandecer a obra de Deus e o prestígio de um rico e poderoso financiador" (Schmitt, 2007, p. 44). Por seu caráter precioso, é também o elemento ideal para evocar o divino, mas não somente: seu brilho, ressaltado pela luz de velas e lamparinas colocadas diante das imagens medievais, despertam o interesse do fiel dentro do edifício religioso, em geral submerso em penumbras, servindo como elemento de intermediação entre esse objeto e o fiel, e permitindo que ele desempenhe de forma eficaz suas funções religiosas.
} 
moderna de Florença"28. Ao contrário do que ocorre a partir do século XIV e posteriormente, quando há um grande desenvolvimento artístico na cidade, com as muitas comissões vindas de famílias abastadas e da própria Igreja, não há, no fim do século XIII, outros trabalhos artísticos que possam rivalizar, em termos de qualidade e beleza, com a imponente decoração da cúpula de San Giovanni. É evidente, desse modo, que esses mosaicos impactam os artistas de fins do século XIII e do XIV, influenciando suas próprias produções.

Como exemplo, podemos mencionar a ascendência da representação do Juízo Final no mosaico sobre Giotto mesmo, enquanto trabalha em Pádua. É claro como o Diabo do Batistério permanece na memória visual do pintor florentino ao conceber sua própria representação do rei dos infernos em sua cena do Julgamento Final: este possui o mesmo tipo de barba e chifres vistos no mosaico, e de suas orelhas saem igualmente serpentes que agarram condenados. O próprio Diabo, uma vez mais, devora um pecador. Precisamos fazer referência ainda ao fato de que ambos os demônios, tanto no mosaico como no afresco, estão sentados sobre dois monstros, que devoram cada qual um pecador. Por fim, o movimento dos braços das duas figuras se assemelham, enquanto suas mãos agarram, cada uma, um condenado.

Há outro elemento iconográfico que também pode ser considerado nessa comparação específica. No afresco paduano, com efeito, alguns autores identificam um pecador que está com as vísceras expostas como Judas, embora não haja qualquer tarjeta ou inscrição, nem a bolsa de dinheiro que costuma identificá-lo. É possível respaldar essa hipótese a partir de fontes escriturais e teológicas, como o fazem Derbes e Sandona ${ }^{29}$. Além do mais, a proximidade com outras figuras enforcadas com suas bolsas de dinheiro - a representação tradicional dos usurários e dos avaros, de quem Judas é um dos principais exemplos para os cristãos - tornam plausíveis tanto a hipótese da identificação dessa figura como Judas, como

\footnotetext{
28 Wilkins, 1927, p. 02.

29 Derbes e Sandona, 1998, p. 280 e 281. Ver também At 1, 16-18: “homens irmãos, convinha que se cumprisse a Escritura que o Espírito Santo predisse pela boca de Davi, acerca de Judas, que foi o guia daqueles que prenderam a Jesus; era contado entre os nossos e recebera sua parte nesse ministério. Ora, este homem adquiriu um terreno com o salário da iniquidade e, caindo de cabeça para baixo, arrebentou pelo meio, derramando-se todas as suas entranhas". Indicações à exposição das vísceras de Judas também são encontradas em textos do século XIII. Para referências a textos com a mesma indicação, ver o artigo citado.
} 
também a possibilidade da ascendência do mosaico florentino de San Giovanni sobre o afresco giottesco nesse ponto específico.

Tratando agora das relações entre literatura e pintura, e da suposta primazia da primeira sobre a segunda, percebe-se como, nos exemplos apresentados, parece ter ocorrido o caminho inverso ao aceito tradicionalmente; com efeito, é hoje um consenso entre os especialistas o fato de que a representação do Juízo Final na cúpula do Batistério de Florença afeta de algum modo a produção literária de Dante. A maior parte dos pesquisadores admite a possibilidade de que o mosaico florentino possa ter sido a principal fonte de influência sobre Alighieri ao pensar seu Inferno, e particularmente o Diabo, descritos em sua Commedia.

Por certo, não devemos, de modo algum, descartar a possibilidade da existência de outras fontes visuais, e que poderiam igualmente ter exercido alguma influência sobre Dante. Hermann Gmelin, por exemplo, indica analogias entre algumas passagens do poema e mosaicos que Alighieri pode ter visto em seu exílio em Ravena ${ }^{30}$. É possível ainda que outras fontes visuais possam eventualmente ter se perdido com o passar dos séculos ${ }^{31}$. Por fim, devemos considerar, nessas digressões, que o poeta florentino também pode ter se baseado somente em fontes literárias, embora essa hipótese pareça a menos plausível.

Sobre o desenvolvimento dos tipos iconográficos nas representações do Inferno, o medievalista francês Jérôme Baschet afirma que um exame tanto das fontes visuais como das escritas "coloca em evidência convergências entre as diferentes fontes, e também indícios de uma circulação de motivos entre a literatura das visões, os exempla, o teatro e a iconografia (...). Praticamente não há motivo iconográfico em que não se possa encontrar (...) um equivalente textual"32. Se o inverso pode ser mais difícil de ser demonstrado, não devemos, no entanto, de forma alguma descartá-lo. Afinal, de modo geral a Idade Média foi marcada por

\footnotetext{
30 Cf. Battaglia Ricci, 2000, p. 64, nota 35.

${ }^{31}$ Giovanni Boccaccio, por exemplo, registra a presença de um Lúcifer na antiga igreja florentina de San Gallo (destruída no século XVI), onde Sansovino também menciona a pintura de um "diabo com muitas bocas". Poderiam se tratar da mesma representação demoníaca? Cf. Battaglia Ricci, 2000 , p. 66, nota 37.

32 Baschet, 1993, p. 503.
} 
profundas e estreitas inter-relações entre textos e imagens. Por conseguinte, como pondera Wilkins, "uma influência desses mosaicos, ainda que não exclusiva, pode ter sido significante na formação de um conceito resultando da combinação de várias sugestões"33.

Ainda com relação ao provável aporte do mosaico do Batistério de San Giovanni sobre o poeta, é preciso considerar a amizade que possivelmente une Dante e Giotto. Exilado de Florença desde o início de 1302, como consequência de disputas e divergências políticas, Alighieri está por conta disso afastado da região da Toscana. Viajando constantemente entre cidades do Vêneto por volta de 1305-1307, podemos supor uma passagem do poeta por Pádua enquanto Giotto está afrescando a Capela Scrovegni; mesmo que pintor e poeta ainda não se conheçam pessoalmente, a notícia de que o principal artista toscano está trabalhando na cidade provavelmente desperta seu interesse. As possíveis relações entre eles (ou ao menos a fama que ambos já têm) podem ter permitido o acesso de Alighieri à capela ainda durante a execução do ciclo, de modo que também a imagem do Inferno giottesco - já inspirado, conforme visto, no mosaico florentino que Dante tão bem conhece - sirva como fonte de inspiração para o poeta.

Acerca uma vez mais das possíveis ascendências sobre Dante, recordemos que, embora a Commedia só seja concluída pouco antes da morte do poeta florentino, em 1321, ela é iniciada com toda probabilidade por volta de $1306^{34}$ - exatamente nos anos em que Giotto está trabalhando na decoração da Capela Scrovegni, com sua ampla cena do Juízo Final. Assim, o afresco giottesco e os debates entre pintor e poeta podem de algum modo ter influenciado a redação da Commedia pouco tempo depois da passagem de Dante por Pádua.

É preciso ter em conta, nesse sentido, que o objetivo principal do poeta florentino com a Commedia é a conversão e a salvação do homem,

\footnotetext{
33 Wilkins, 1927, p. 08.

34 Segundo Giorgio Petrocchi, o Inferno pode ter sido redigido entre 1304 e 1306, porém mais provavelmente entre 1306 e 1309; o Purgatorio teria sido iniciado em 1308; o Paradiso, por fim, já estaria sendo escrito em 1316. Petrocchi, 2004, p. 102, 147 e 190. Os cantos foram sendo divulgados individualmente, após sua conclusão por Dante. Sendo assim, o Inferno teria sido provavelmente publicado na segunda metade de 1314, e o Purgatorio no outono de 1315 . O canto do Paradiso foi tornado público pouco depois da morte do poeta, ocorrida em 14 de setembro de 1321. Idem, p. 190 e 224.
} 
precisamente uma das funções religiosas primordiais que se espera de uma representação visual do tema do Juízo Final. Desse modo, percebemos as inter-relações que podem ter sido estabelecidas entre Giotto e Dante, a partir de temas que possuem objetivos em comum, sempre tendo em mente as especificidades da pintura e da poesia.

Nessa rede de relações, também devemos necessariamente incluir o mosaico de Coppo di Marcovaldo no Batistério de Florença. Sem dúvida, a descrição do Diabo dantesco, embora não seja um espelho do demônio de Coppo e, por analogia, também daquele pintado por Giotto em Pádua, a estes pode ser remetido ${ }^{35}$. Se não há serpentes saindo das orelhas do Diabo, Dante descreve, por outro lado, três cabeças devorando três pecadores, de forma análoga ao que ocorre no Batistério florentino ${ }^{36}$. Diversamente do que ocorre na descrição dantesca, duas das bocas que devoram os condenados são as das serpentes que saem das orelhas da cabeça única do Diabo; a afinidade, porém, entre imagem e descrição poética é manifesta.

Por fim, não podemos nos esquecer, nessa análise, da figura de Judas. É possível conjecturar que as representações de Judas enforcado no mosaico florentino (onde é explicitamente identificado) e no afresco paduano possam ter inspirado Dante a colocá-lo como o principal pecador em destaque em sua Commedia? Afinal, ele é descrito sendo devorado pela cabeça central do Diabo, como o maior de todos os pecadores, por ter traído o Cristo ${ }^{37}$. De fato, ao mesmo parece aludir o Judas do Batistério, uma vez que é o único pecador mencionado com uma inscrição específica, conforme visto. E provavelmente não é apenas coincidência o fato de que tanto no Juízo Final do Batistério, como no da Capela Scrovegni, do pecador central se veja somente a metade inferior, enquanto a cabeça é "abocada" pelo demônio, conforme descreveria Dante em seu poema pouco depois, enquanto os outros dois pecadores são representados de ponta cabeça, o que também é seguido pelo poeta florentino ${ }^{38}$.

\footnotetext{
35 Diversas passagens da Commedia referentes à descrição do Diabo foram já transcritas no presente artigo. A longa passagem completa pode ser encontrada em Inf. XXXIV, 37-54.

36 "Da ogne bocca dirompea co' denti/ un peccatore, a guisa di maciulla,/ sí che tre ne facea così dolenti" ["Em cada boca um pecador, com cruentos/ dentes, moía à feição de gramadeira,/ aos três prestando, de vez, seus tormentos"]. Inf. XXXIV, 55-57.

37 Inf. XXXIV, 58-63. Passagem já reproduzida anteriormente neste artigo.

38 Inf. XXXIV, 64-67. Passagem também já transcrita no presente artigo.
} 
Podemos perceber, assim, como o grande poema fundador da língua italiana, no fim das contas, possivelmente deva bastante ao repertório visual acumulado por Dante ao longo de sua vida. Para encerrar este artigo, reforçando as possibilidades de diálogo e influências entre artes visuais e literatura, queremos apresentar de forma breve um último exemplo, não propriamente florentino, ainda que realizado com toda probabilidade por um artista de Florença, e que, portanto, recebe as influências artísticas dessa cidade. Trata-se do já mencionado ciclo do Trionfo della Morte, no Camposanto de Pisa, considerado "um dos eventos pictóricos mais significativos do primeiro Trecento", conforme definição de Battaglia Ricci39. Tradicionalmente se acreditava que a iconografia do primeiro afresco do ciclo, intitulado precisamente Triunfo da Morte, houvesse se inspirado no Decameron, de Giovanni Boccaccio (1313-1375), devido às analogias que podem ser estabelecidas entre o texto e alguns aspectos da iconografia representada na cena, de que trataremos em seguida.

O Decameron, assim como a Commedia, alguns anos antes, é texto fundamental para o desenvolvimento da literatura italiana ${ }^{40}$. Recordemos, de início, a datação do texto boccacciano: as histórias do livro se passam em 1348, durante o grande surto de Peste Negra, e Boccaccio, provavelmente, não as inicia antes dos anos 1350 . Os críticos tendem a crer que a redação do texto está em curso ainda em 1353. Boccaccio certamente finaliza o livro na segunda metade da década de 1350, considerando-se que a mais antiga menção a ele está em uma carta de 1360.

A historiografia considerava que o maestro do Camposanto ${ }^{41}$ havia se inspirado no Decameron de Boccaccio para a realização do afresco do Trionfo della Morte; percebemos aqui, sem dúvida, a visão tradicional pela qual a literatura, o texto escrito, deve ter necessariamente precedência em relação ao documento visual. Por conta disso, por um longo período

\footnotetext{
39 Battaglia Ricci, 2000, p. 57.

40 Não somente da italiana: podemos pensar, por exemplo, nas similaridades entre o Decameron e as Canterbury Tales, de Geoffrey Chaucer (ca.1343-1400), escritas no último quartel do século XIV. Sobre a importância do texto de Boccaccio, cuja estrutura literária, bastante inovadora, influencia a novellistica italiana do Trecento, ver Battaglia Ricci, 2000, p. 19-29.

${ }^{41}$ A atribuição do ciclo a Buffalmacco é relativamente recente e, embora aceita atualmente pela maior parte dos especialistas, ainda é motivo de debates entre os pesquisadores.
} 
de tempo não foi posta em discussão a datação do ciclo de afrescos. Se não era possível precisar a data de concepção e execução das pinturas, devido à falta de documentação, partia-se do pressuposto, por outro lado, de que as cenas certamente teriam sido executadas após o surto de Peste Negra e, mais ainda, após a publicação do Decameron.

De fato, conforme comentado anteriormente, o ciclo é composto por quatro cenas - Triunfo da Morte, Juízo Final, Inferno e Tebaide -, em que prevalece uma interpretação negativa do homem e de seu destino no Além, pois, após o triunfo da morte e o fim dos tempos, explicita-se somente a possibilidade da condenação eterna no Inferno, tendo em vista que a este não se contrapõe o Paraíso propriamente dito. O impacto da mensagem pessimista do ciclo se torna ainda mais evidente quando consideramos que ele se encontra em um local de sepultamento, e a estrutura arquitetônica do Camposanto ${ }^{42}$ faz com que originalmente os fiéis visualizassem as cenas nessa ordem precisa.

De acordo com o historiador da arte norte-americano Millard Meiss (1904-1975), que publica em 1951 um livro fundamental sobre a arte em Florença e Siena após a Peste Negra, os afrescos do Camposanto de Pisa teriam sido realizados poucos anos após o grande surto de 1348, expressando, portanto, de modo vívido uma tragédia recém-ocorrida. A Peste Negra, com efeito, é considerada um fundamental divisor de águas no que se refere às mudanças nas mentalidades religiosas em fins do Medievo, cujas consequências podem ser percebidas em aspectos diversos da vida ao menos até as primeiras décadas do século XV segundo a hipótese de Meiss, também nos desenvolvimentos artísticos do período 43 .

Como afirmado anteriormente, essa foi a posição aceita pela historiografia da arte ao menos até o fim dos anos 1970. No entanto, evidências levantadas por novas pesquisas mostram que, no caso específico dos afrescos pisanos, as ideias de Meiss não podem se

\footnotetext{
42 O Camposanto de Pisa, vale recordar, não é um cemitério comum; ele é um edifício térreo com um jardim interno, conformação que o torna semelhante a claustros de mosteiros e conventos. Fiéis que o frequentassem caminhariam ao redor do jardim interno, seguindo um percurso prédefinido.

43 Sobre isso, ver Meiss, 1964. Para uma discussão sobre a importância da Peste Negra para a religiosidade da segunda metade do século XIV, ver Quírico, 2012.
} 
sustentar. Não é possível retomar neste artigo toda a discussão acerca da atribuição e da datação do ciclo do Camposanto. Para isso, há uma farta bibliografia disponível ${ }^{44}$. Cabe mencionar, porém, que o historiador da arte italiano Luciano Bellosi (1936-2011), que publica em 1974 o livro Buffalmacco e il Trionfo dela Morte, é quem efetivamente propõe uma nova perspectiva acerca do ciclo de Pisa, e que é atualmente aceita pela maior parte dos pesquisadores.

A historiografia da arte contemporânea, de fato, considera que a popularização dos chamados Trionfi - representações visuais do Triunfo da Morte, de que o afresco do Camposanto de Pisa é um dos primeiros exemplos - está relacionada, assim como o tema da Dança Macabra e o do Encontro dos três vivos com os três mortos (presente, inclusive, no próprio afresco pisano do Triunfo, na extremidade esquerda da cena), a uma cultura da penitência que se liga a uma "tendência à vida ascéticoeremítico-penitencial que a Toscana do século XIV conhecia e amplamente praticava há diversas décadas" 45 . Desde, portanto, muito antes do grande surto de Peste Negra.

Ainda segundo Battaglia Ricci, no início do século XIV ocorrem mudanças nas noções acerca do quotidiano e de como vivê-lo, buscando "uma vida mais refinada e mais aberta ao prazer estético"46. Isso gera, por exemplo, modificações também nos locais de moradia de uma elite social que, de casas-torres, passam a ser palacetes com jardins intramuros. Decerto não por acaso, na extremidade direita do Triunfo há um grupo de jovens se divertindo no interior de um recinto ajardinado, cercado por árvores frutíferas. Há, portanto, uma clara relação entre mudanças sociais que ocorrem no início do Trecento e escolhas iconográficas específicas feitas no afresco do Triunfo da Morte. Ao analisarmos todo o conjunto de pinturas, percebemos como o ciclo deve ser interpretado à luz de uma crítica a modelos culturais e de vida ligados a uma visão de mundo derivada, em última instância, das cortes francesas e provençais criada entre os séculos XII e XIII ${ }^{47}$.

\footnotetext{
44 Uma modesta contribuição em português pode ser lida em Quírico, 2015.

${ }^{45}$ Battaglia Ricci, 2000, p. 54.

${ }^{46}$ Battaglia Ricci, 2000, p. 125.

47 Vale lembrar que o já mencionado tema do Encontro dos três vivos com os três mortos foi desenvolvido pela literatura francesa a partir do texto Dict des trois morts et des trois vifs, de Baudoin de Condé, escrito nas últimas décadas do século XIII.
} 
Essa concepção, aliada à busca por um modelo de vida mais penitente, nos ajuda a compreender que a mensagem do ciclo pisano é, com toda probabilidade, dirigida a uma classe citadina bem específica, não particularmente preocupada com essas questões. Trata-se, é claro, de uma crítica aos prazeres do mundo, que pode ser compreendida por todos os fiéis; o que se apresenta na pintura do Triunfo da Morte, no entanto, não é um juízo generalista; pelo contrário, são mostrados os deleites ligados a uma elite social pisana, representada com destaque em todo o primeiro afresco do ciclo ${ }^{48}$. Basta percebermos os elegantes trajes do grupo que retorna da caça na metade esquerda da pintura para compreendermos que estamos diante de figuras abastadas; ademais, conforme já mencionado, na extremidade direita da cena, divertindo-se distraidamente com instrumentos musicais diversos no jardim, está um grupo de jovens também ricamente vestidos, enquanto a Morte (cuja alegoria é destacada de forma brutalmente evidente na região central da pintura) parece se aproximar. As distrações dos jovens no jardim e na caçada se opõem às atividades dos eremitas representados na parte superior esquerda do afresco do Triunfo, que buscam, através do ascetismo e da meditação dos textos sagrados, a remissão dos pecados e a salvação ${ }^{49}$.

Retomemos, portanto, após essas breves, porém importantes, digressões, as relações e ascendências entre artes visuais e literatura. Presentemente, considerando-se a possível datação dos afrescos pisanos - decerto anterior a 1348 -, compreendemos que, no caso específico do ciclo do Trionfo della Morte, o eixo de influência deve necessariamente ter ocorrido no sentido inverso: o mais plausível é que Boccaccio, ao ver o afresco, tenha se inspirado para compor sua obra mais famosa. Devemos ressaltar que não há registro de uma viagem de Boccaccio a Pisa, o que não significa, de modo algum, que por lá não tenha passado. Dada a importância que o escritor concede às artes figurativas, não seria equivocado supor que possa ter ido a Pisa para admirar um dos ciclos de

\footnotetext{
48 Não por acaso, escreve Battaglia Ricci que "a sintomática ausência de pobres no grupo dos cadáveres [representado na área central da pintura] se poderia explicar considerando que evidentemente não são os 'pobres' o público implícito do afresco". Battaglia Ricci, 2000, p. 117. ${ }^{49}$ A oposição também se dá, conforme nos recorda Battaglia Ricci, através do vestuário. Afinal, "à variada, multiforme, auto-significativa beleza das vestes dos jovens 'na moda' se opõem as austeras túnicas dos anacoretas, cujas cores 'significam' vida de penitência e renascimento espiritual". Battaglia Ricci, 2000, p. 163.
} 
afrescos mais significativos da época, conforme já comentado. Por outro lado, se não podemos afirmar isso de modo categórico, precisamos recordar que dificilmente Boccaccio não tenha visto o atualmente fragmentário ciclo do Trionfo della Morte (ca.1350) pintado por Andrea Orcagna em Santa Croce, e cujas descrições e fragmentos permitem supor que fosse praticamente idêntico ao Triunfo pisano, ao menos no trecho que nos interessa: a Morte que, sobre a pilha de cadáveres, desloca-se em direção aos jovens no jardim (não por acaso Vasari atribui ambos os ciclos - o de Pisa e o de Florença - ao mesmo Orcagna ${ }^{50}$ ).

Portanto, seja vendo diretamente o ciclo em Pisa, seja contemplando sua versão florentina em Santa Croce, é provável que Boccaccio tenha daí tirado elementos fundamentais para seu texto. No Decameron, com efeito, a lieta brigata dos jovens que fogem da peste (os chamados novellieri) são dez, assim como no grupo de jovens do Trionfo. Em ambos os casos, trata-se de três homens e sete mulheres ${ }^{51}$, todos de elevada condição social. Não somente: é no afresco pisano que parece se instituir, pela primeira vez, a associação entre a fuga da morte e um jardim recordemos que, no texto de Boccaccio, é por causa da mortandade provocada pelo surto de 1348 que os jovens decidem fugir da cidade de Florença, buscando refúgio em locais amenos e ajardinados, como

\footnotetext{
${ }^{50}$ Escreve Vasari nas Vite que "se ne tornò Andrea a Fiorenza, dove, nel mezzo della Chiesa di Santa Croce, a man destra, in una grandissima facciata, dipinse a fresco le medesime cose che dipinse nel Campo Santo di Pisa, in tre quadri simili, eccetto però la storia dove San Macario mostra a' tre re la miseria umana, e la vita de' romiti che servono Dio su quel monte. Facendo, adunque, tutto il resto dell'opera, lavorò in questa con miglior disegno e più diligenza che a Pisa fatto non avea, tenendo nondimeno quasi il medesimo modo nell'invenzione, nelle maniere, nelle scritte e nel rimanente senza mutare altro che i ritratti di naturale" ["Voltou Andrea a Florença, onde, no meio da Igreja de Santa Croce, do lado direito, em uma grandíssima fachada, pintou em afresco as mesmas coisas que pintou no Campo Santo de Pisa, em três quadros semelhantes, exceto porém a história onde São Macário mostra aos três reis a miséria humana, e a vida dos eremitas que servem a Deus naquele monte. Fazendo, portanto, todo o resto da obra, trabalhou nesta com melhor desenho e mais diligência do que havia feito em Pisa, mantendo no entanto quase o mesmo modo na invenção, nas maneiras, nas escritas e no resto sem mudar algo que não os retratos do natural"]. Vasari, 1997 , p. 214 e 215.

51 "Comincia il libro chiamato Decameron cognominato prencipe Galeotto, nel quale si contengono cento novelle in diece dì dette da sette donne e da tre giovani uomini" ["Tem início o livro intitulado Decameron, cognominado príncipe Galehautt, no qual estão contidas cem novelas narradas em dez dias por sete mulheres e três homens"]. Incipit do proêmio. Galehautt, em italiano Galeotto, recorde-se, faz referência ao melhor amigo de Lancelot, nas novelas do ciclo arturiano.
} 
também é mostrado no afresco. Distraídos em suas diversões, alheios ao que ocorre fora do jardim, os jovens não percebem a proximidade da Morte que, foice em mãos, parece se dirigir a eles após deixar um rastro de corpos atrás de si.

Entretanto, devemos ressaltar que, ainda que Boccaccio tenha se inspirado nas pinturas para escrever seu texto, as questões norteadoras da elaboração compositiva e iconográfica do ciclo do Camposanto de Pisa parecem muito distantes daquelas que levam à redação do Decameron em data próxima. De fato, enquanto os afrescos pisanos exaltam um modelo de vida ascético-eremítico-penitencial, Boccaccio, de sua parte, valoriza o ideal de vida aristocrático e o amor cortês, indicando que a Peste Negra não somente dizima parte da população toscana, mas destrói também as normas sociais, assim como os usos e costumes que the são caros. As analogias entre pintura e texto, porém, são uma vez mais manifestas.

Ao chegarmos à conclusão de nosso artigo, podemos perceber de forma clara que, ainda que não seja tão frequente - ou, pelo menos, que não seja tão estudado ou destacado por pesquisas -, não é de todo raro que haja exemplos em que ocorra a inversão da visão tradicional do domínio do texto sobre a imagem. A Commedia e o Decameron, duas das grandes obras-primas da literatura italiana do Trecento, talvez sejam os melhores representantes dessa afirmação. Quantos mais não podem existir?

\section{Referências}

BASCHET, J. Les justices de l'au-delà. Les représentations de l'enfer en France et en Italie (XIIe-XVe siècle). Roma: École Française de Rome, 1993

BATTAGLIA RICCI, L. Ragionare nel giardino: Boccacio e i cicli pittorici del Trionfo della morte, $2^{\mathrm{a}}$ edição. Roma: Salerno, 2000 [1987]

BELLOSI, L. Buffalmacco e il trionfo della morte. Turim: Einaudi, 1974

BOCCACCIO, G. Decameron, 2 volumes (org. V. Branca). Turim: 1992

. Decameron (trad. I.C. Benedetti). Porto Alegre: L\&PM, 2013

CONSOLI, C. "Il Giudizio Finale del Battistero di Firenze e il suo pubblico". In: Quaderni medievali (9), junho de 1980 
CROCIANI, L. "The iconography of the Baptistery". In: LORENZI, L. Devils in art. Florence, from the Middle Ages to the Renaissance (trad. M. Roberts). Florença: Centro Di, 1997

DANTE ALIGHIERI. A Divina Comédia, 3 volumes. Edição bilíngue (tradução e notas de I.E. Mauro). São Paulo: 34, 1998

DERBES, A. e SANDONA, M. "Barren metal and the fruitful womb: the program of Giotto's Arena Chapel in Padua". In: The Art Bulletin, volume LXXX, n. ${ }^{\circ} 1$, junho de 1998

FRUGONI, C. "Altri luoghi, cercando il Paradiso (il ciclo di Buffalmacco nel Camposanto di Pisa e la committenza domenicana)". In: Annali della Scuola Normale Superiore di Pisa. Série III, vol. XVIII, n. ${ }^{\circ} 4$. Pisa, 1988

GARZANTI LINGUISTICA. Disponível em: <https://www.garzantilinguistica.it/ricerca/?q=tebaide>. Acesso em 02.07.2019

GRASSI, L. "Il concetto di 'moderno' in rapporto a Giotto nella riflessione del pensiero critico del Trecento". In: Giotto e il suo tempo. Atti del convegno internazionale per la celebrazione del VII centenario della nascita di Giotto. Roma: De Luca, 1971

MEISS, M. Painting in Florence and Siena after the Black Death. Princeton: Princeton University, 1964 [1951]

NOGUEIRA, C.R.F. O diabo no imaginário cristão. Bauru: EDUSC, 2000

PETROCCHI, G. Vita di Dante, 4ª edição. Roma e Bari: Laterza, 2004 [1983]

QUEIROZ, T.A.P. “Aprender a saber na Idade Média”. In: MONGELLI, L.M. (coord.). Trivium e Quadrivium. As artes liberais na Idade Média. Cotia: Íbis, 1999

QUÍRICO, T. "Sobre datação e atribuição de obras de arte: o caso do ciclo do Trionfo della Morte no Camposanto de Pisa". In: Diálogos Mediterrânicos, volume 8, 2015

Inferno e Paradiso. As representações do Juízo Final na pintura toscana do século XIV. Campinas: Unicamp, 2014 (2014a) 
- "The representation of Heaven and Hell in Last Judgement scenes". In: PICCAT, M.; RAMELLO, L. (Org.). Memento Mori. II genere macabro in Europa dal Medioevo a oggi. 1ed. Alessandria: Edizioni dell'Orso, 2014, volume 1 (2014b)

- "Peste Negra e escatologia. Os efeitos da expectativa da morte sobre a religiosidade do século XIV”. In: Mirabilia. Vitória, 2012, vol. 14

SCHMITT, J.C. O corpo das imagens. Ensaios sobre a cultura visual na Idade Média (trad. J.R. Macedo). Bauru: EDUSC, 2007 [2002]

VASARI, G. Le vite dei più eccellenti pittori, scultori ed architetti, $3^{\mathrm{a}}$ edição. Roma: Newton \& Compton, 1997 [1568]

WILKINS, E.H. "Dante and the mosaics of his Bel San Giovanni". In: Speculum, volume II, n. ${ }^{\circ} 01$, janeiro de 1927 